\title{
IMPACT OF CHANGES IN COMPOSITION OF EXCHANGE PRICE INDEX SHARES OF LISTED POLISH COMPANIES
}

\author{
Krzysztof Wańczyk \\ University of Economics in Katowice, Katowice, Poland \\ e-mail: krzysztof.wanczyk@gmail.com
}

ORCID: 0000-0002-0610-8763

\section{(C) 2018 Krzysztof Wańczyk}

This is an open access article distributed under the Creative Commons Attribution-NonCommercial-NoDerivs license (http://creativecommons.org/licenses/by-nc-nd/3.0/)

DOI: $10.15611 /$ fins.2018.3.09

\begin{abstract}
The aim of the article is to analyse the change in the quotations of Polish listed companies, which change the stock exchange index as part of the periodic change in the composition of the WIG20, mWIG40 and sWIG80 stock market indices. The research methodology uses abnormal return (AR) based on daily logarithmic rates of return of Polish listed companies and daily logarithmic rates of return on the stock market indices (WIG20, mWIG40, sWIG80). In this way, they defined the relative strength of listed shares in relation to the stock indices revision a month before the composition of the stock index, when the drawn up list of companies is changing the composition of the index. In addition, the relative strength of quoted shares in relation to stock exchange indices after the revision of the composition of the stock exchange index in the short-term (one month) and medium-term perspective (six months) was examined. The research was based on quarterly changes in the composition of stock exchange indices in the years 2010-2015. The analyses carried out indicate the existence of positive surplus stock returns a month before the change in the stock index. The average number of quotes of these companies above the stock market index at the time amounted to +0.52 percentage points. In turn, the average increase in the prices of the debuting companies in the new stock exchange index within 6 months after their flotation it amounted to +0.97 percentage points over the benchmark (WIG20, mWIG40, sWIG80).
\end{abstract}

Keywords: stock market index, Stock Exchange in Warsaw, capital market, investment strategy.

\section{Introduction}

At the end of 2016, 486 companies were listed on the Warsaw Stock Exchange. The selection of such a large number of companies is a very difficult task for the investor, which is why the board of the Stock Exchange introduced a division of listed companies according to strictly defined criteria. In this way stock indices were created aimed at introducing a clear picture of the situation on the securities listing market. One of the basic criteria for the classification of companies is the level of 
market capitalization. On this basis, such indices as: WIG20, mWIG40 and sWIG80 were created. All three stock indices collectively group 140 of the largest and most liquid companies from the main WSE market. Every third Friday of the new quarter of the calendar year, the composition of these indexes is revised.

The aim of the article is to analyse the change in stock quotes that enter the WIG20, mWIG40 and sWIG80 index. The research methodology uses the surplus rate of return (abnormal return, AR). With this measure, the relative strength of the listed shares will be determined relative to the stock indices, one month before and six months after the change in the index classification. The results of the analyses are to help investors make the right decision to buy or sell shares. The issue taken up in this work is part of the author's larger research on the effectiveness of the Polish stock market.

\section{Research}

Research on the impact of the change in the index classification on the stock quotes conducted in the world, focuses mainly on the US market. Most often, they relate to the listing of companies from the Russell 3000 index to the Russell 2000 and the Russell 1000 index. In the context of the present research it is important that the Russell 3000 index was the model for the existing sWIG80 stock index in Poland, the Russell 2000 index became an inspiration to create the mWIG40 index, and the Russell 1000 index was an example for the creation of the WIG20 index.

The analysis of the change in the index classification and its impact on the quotations and liquidity of the actions were repeatedly published in the literature [McConnell, Sanger 1984; Grammatikos, Papaioannou 1986; Baker, Edelman 1992; Kadlec, McConnell 1994]. The common conclusion for most of these studies is that the share price increases directly before the change in the stock index, and then decreases after this event. After entering the stock indices the liquidity of quotations improves, but the scale of this phenomenon is largely dependent on the level of liquidity before the change of quotations [Kadlec, McConnell 1994].

Studies analysing mainly the liquidity effect permitted to conclude that entry to the stock index reduces the volatility of quotations and provides investors with lower transaction execution costs [Bessembinder 1999; Bennet, Wei 2005]. In addition, it contributes to the narrowing of transactional spreads [Sapp, Yan 2003]. Long-term entry of the issuer to the main index means higher interest in shares on the part of institutional investors and analysts, which probably results from more quotes and recommendations [Merton 1987]. There is also a shortage of research opposed to commonly observed regularities [Pankaj, Jang-Chul 2006].

Extensive research on the British market was conducted by Jenkinson and Ramadorai [2008]. As a result of the conducted research, they found a positive effect of announcing the intention to enter the stock exchange index. The average positive 
rate of return was around 5\%. After entering, the transition effect turned out to be neutral, although in some cases slightly negative abnormal returns were observed.

The author, in spite of thorough search, did not find any study on other European markets, including Poland, corresponding to the research subject of this article.

\section{Rules for creating portfolios of indices}

The basic criterion for the classification of companies for a given stock exchange index is the total value of shares in free float and their percentage share in the total turnover of all companies. On the basis of these principles the stock exchange in Warsaw creates the so-called ranking list of companies. It is used to create a new composition of stock market indices based on the most up-to-date data. The deadline for the ranking to be revised annually and quarterly adjustments is four weeks before the change. The portfolio portfolios are published after the annual or quarterly revision, two weeks before the change. However, the portfolio composition change date falls after the session on the third Friday of March for the annual revision and the third Friday of June, September and December for the quarterly adjustment. The determination of turnover parameters for the needs of the ranking is based on data from the last twelve months. The capitalization of free-float shares is determined randomly, based on the closing rate of the last five sessions before the ranking date [GPW Resolution no 832/2016, 2016]. The table below presents the process of changing the composition of stock exchange index portfolios.

Table 1. The process of changing the composition of stock exchange index portfolios

\begin{tabular}{|l|l|}
\hline \multicolumn{1}{|c|}{ Process } & \multicolumn{1}{c|}{ Rules } \\
\hline $\begin{array}{l}\text { The term of the ranking for annual revision and } \\
\text { quarterly adjustments }\end{array}$ & 4 weeks before the change \\
\hline $\begin{array}{l}\text { The date of the portfolio announcement after the } \\
\text { annual revision or quarterly adjustment }\end{array}$ & 2 weeks before the change \\
\hline $\begin{array}{l}\text { The date of portfolio changes as part of the } \\
\text { annual audit }\end{array}$ & $\begin{array}{l}\text { Third Friday in March, June and September } \\
\text { and December }\end{array}$ \\
\hline $\begin{array}{l}\text { Setting parameters for the purposes of the } \\
\text { ranking }\end{array}$ & $\begin{array}{l}\text { Trading for the last 12 months, free capitalization } \\
\text { on a random basis, based on the selected } \\
\text { exchange rate from the last 5 sessions before the } \\
\text { ranking day }\end{array}$ \\
\hline Free market capitalization criterion & $\begin{array}{l}\text { Companies are not eligible for the ranking } \\
\text { from the last quartile of the statement by } \\
\text { capitalization in free circulation }\end{array}$ \\
\hline
\end{tabular}

Source: prepared on the basis of [GPW Resolution no. 832/2016, 2016]. 


\section{Research methodology}

The studies took into account the commonly used method based on surplus returns (AR - abnormal return) [Fama et al. 1969]. The basic assumption of the method was to determine the relationship between the rate of return on shares of a specific company and the rate of return from the stock index. The discovery of this dependence made it possible to check whether the relationship is still valid after changing the composition of the stock index, or whether it produced a positive or negative surplus rate of return.

In order to calculate surplus rates of return, a model based on the market index (WIG20, mWIG40 or sWIG80) was used depending on which stock index the company was in after the index composition was reviewed. Thus, the analyses included the relative strength of share quotations in relation to the corresponding stock index, to take into account the impact of prevailing market trends on the share prices of the analysed companies. The relative strength of quotations was determined using the surplus rate of return (AR - abnormal return). Quotations of all shares were brought to one time point, assuming that day $t-1$ is the last trading day of companies in the "stock market decade", while day $t 1$ - debut and first listing day in the "new stock exchange index".

The surplus rate of return on the shares of each company was calculated based on the difference between the logarithmic daily rate of return of the company's shares and the logarithmic daily rate of return of the stock exchange index in the $t$-note, which is presented in the formula:

$$
A R_{i t}=R_{i t}-R_{m t},
$$

where: $A R_{i t}$ - surplus rate of return on shares and achieved in the $t$-th listing, $R_{i t}$ - logarithmic rate from the stock gate and achieved in the $t$-th listing, $R_{m}$ - logarithmic rate of return from the stock index $\mathrm{m}$ in $t$-th listing, $t$ - day.

For a given day $t$, the excess rate of return from the stock portfolio debuting in the stock exchange index (AAR) was calculated as the arithmetic average of the surplus daily rates of return of shares subject to analysis.

$$
A A R=\frac{1}{N} \sum_{i=1}^{N} A R_{i T},
$$

where: $A A R$ - arithmetic average of the surplus daily rates of return from shares debuting on the stock exchange index (average abnormal returns), $N$-number of companies in the population studied, $A R_{i t}$ - markings as before.

The research assumes that one month means 20 trading sessions. In order to preserve the transparency of the research results, for the period of $t-20$ the 
contractual value of the price index, unweighted by capitalization or the turnover volume, was introduced at the level of 100 points. This value was adjusted each day with the arithmetic average of the daily excess rate of return (AAR) of the shares that were included in the stock indices WIG20, mWIG40 and sWIG80, respectively. In this way a price index was created reflecting the change in the listings of 20 session companies before and 120 sessions after the change in the stock market index, which corresponds to about a month before and six months after the change in the stock index.

\section{Experimental results}

In the first stage of the research, an analysis of index messages provided by the stock exchange in Warsaw was carried out. Pursuant to the resolution of the WSE management board [Resolution No 832/2016, 2016], index messages are published two weeks before the change in the composition of stock exchange index portfolios on every third Friday in March, June, September and December. In turn, the weighted weeks before the official message exchanges appear for the preliminary estimates indicate that the company may change the composition of the index. As a result, the index messages, which appeared on the [www 1] website in 2010-2015, were taken into consideration. The research did not take into account changes in the composition of the WIG20, mWIG40 and sWIG80 stock exchange portfolios before 2010, as some of these companies are currently not listed on the Warsaw Stock Exchange. The most common reason for the dematerialization of their shares is withdrawal from the market, announcement of a call for sale of shares, change in the ownership structure or financial bankruptcy. Therefore, all the changes in the composition of stock market indices before 2010 were not subject to the conducted tests. The research group selected on this basis was adjusted for companies in a difficult financial situation, i.e. generating a negative financial result at the level of net profit in the observation period, in addition to companies with extremely low prices, the so-called penny companies, whose share price dropped below the market value of PLN 1.00. The reason for the application of such selection criteria of companies is their lack of systematic approach, which would significantly affect the final result of the research.

The research covered 17 companies belonging to the WIG20 index, 36 companies included in the mWIG40 index composition and 88 issuers making their debut in the sWIG80 index in 2010-2015. The analysis covered a month's quotations (20 sessions) of each company before the appearance in the stock exchange index and half a year listings (120 sessions) of each company after its debut in a given stock exchange index.

First, the changes in the quotations of companies that debuted in 2010-2015 in the WIG20 index were analysed. The study shows that during the month prior to the group entry of the most liquid companies, the WIG20, quotes of the analysed 
companies rallied significantly during this period creating an upward trend (Figure 1). The average increase in the value of these companies over the WIG20 index in this period amounted to +2.63 percentage points.

The value of the portfolio increase above the WIG20 index

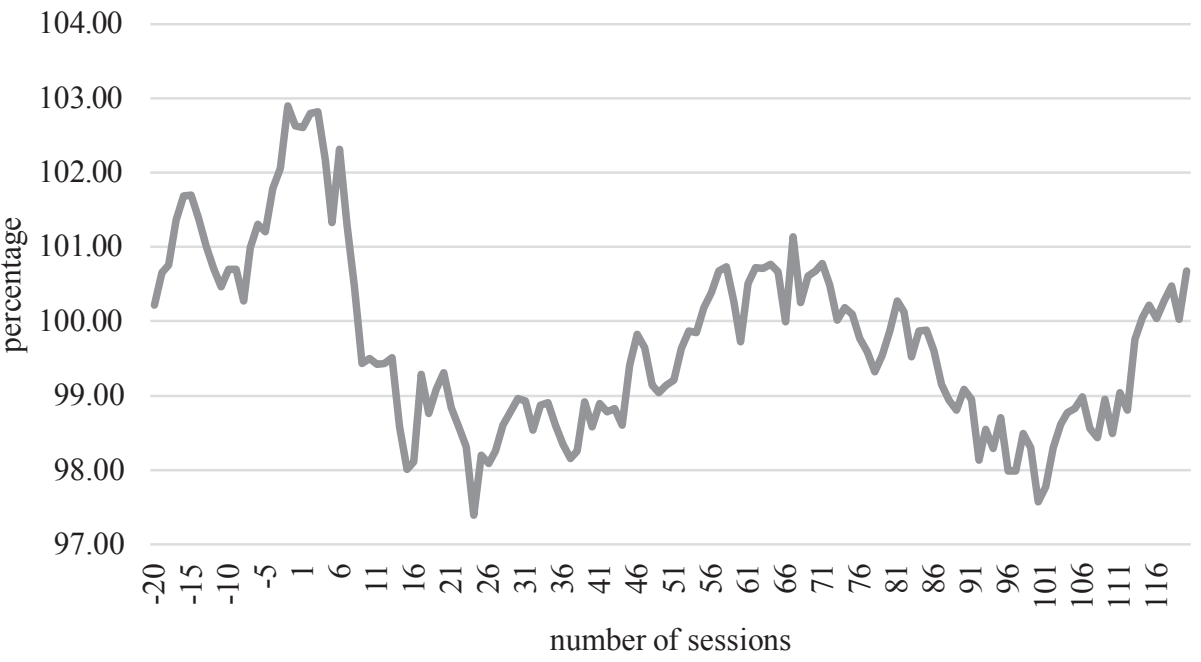

Fig. 1. The value of the portfolio increase above the WIG20 index

Source: own study.

After the company's debut, the WIG20 index shows a reversal of the quotation trends in the analysed research group (Figure 1). The analysis shows that since the first days of quotations in the new stock exchange index, these companies have behaved worse than the benchmark (WIG20). Studies have shown that after the first 20 sessions after the index change, the decline in the value of these companies was 3.23 points percent more than in the WIG20 index. In the longer term, covering a period of six months, no statistically significant change in the listing of companies entering the WIG20 index was observed. The research shows that after half a year the quotations of these companies were worse than the benchmark by 1.90 percentage points. However, during the entire research period ( 7 months), these companies gained a symbolic 0.67 percentage points more than the WIG20 index.

The same analysis was carried out for the mWIG40 stock index, grouping mid-cap companies. The study shows that a month before the mWIG40 index entered the listings of the analysed companies, they moderately decreased to form a downward trend (Figure 2). The average decrease in the value of these companies over the mWIG40 index at that time amounted to 1.16 percent. 
The value of the portfolio increase above the mWIG40 index

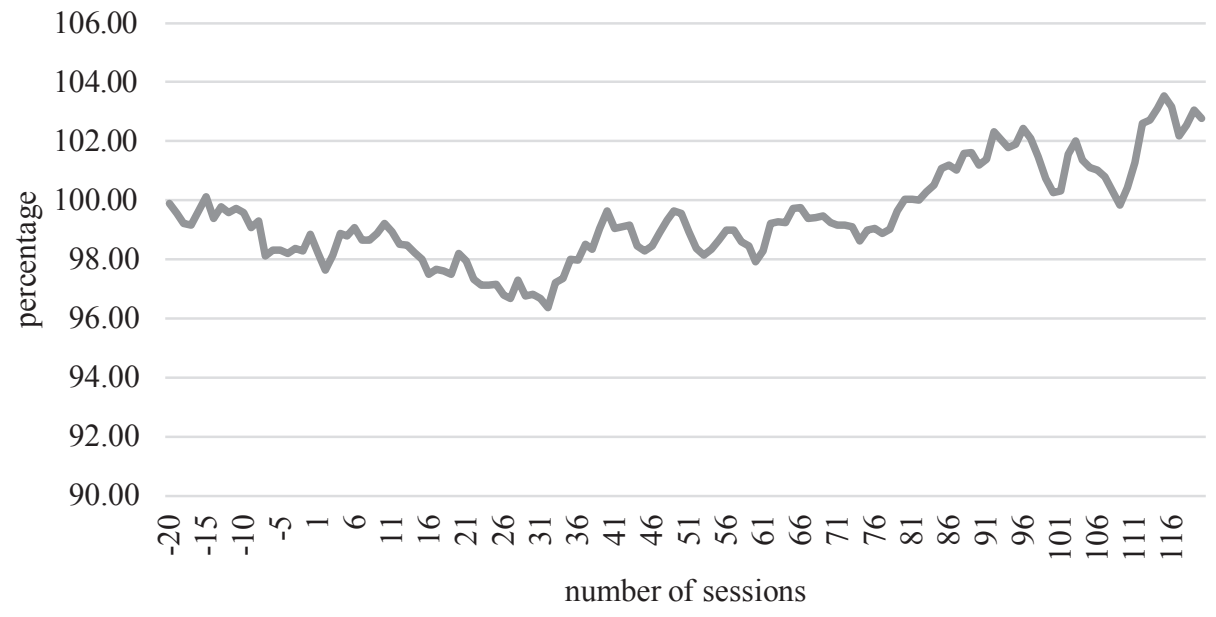

Fig. 2. The value of the portfolio increase above the mWIG40 index

Source: own study.

At the same time, the moment of entry of companies into the mWIG40 index did not turn out to be a breakthrough point for the research group. The analysis shows that in the first month after entering the mWIG40 index, these companies maintained a downward trend and they lost an average of 0.66 percent more than the benchmark (mWIG40). The situation of the analysed companies began to change only in the longer horizon of time when growth was recorded by their quotations. During the six months after its debut in the mWIG40 index, the value of these companies increased by 3.99 percent more from the benchmark (mWIG40). However, during the whole research period ( 7 months), the group of analysed companies behaved better than the benchmark by 2.79 percent.

In the next stage of the research, the analysis of quotations of shares entering the index of the companies with the smallest capitalization on the WSE was conducted, that is to the sWIG80 index. It turned out that within a month before entering the stock index, they did not show any significant reaction to the message about entering the sWIG80 index. Research has shown that they behaved better than the benchmark by only 0.09 percentage points.

A significantly larger increase in the surveyed companies was observed in the first month after its debut in the sWIG80 index. The analyses show that they grew at that time by 3.52 percent more than the benchmark (sWIG80). However, in the long term covering a period of six months after the entry of the company into sWIG80, the researched company grew an average 0.83 percent more than the benchmark 
The value of the portfolio increase above the sWIG 80 index

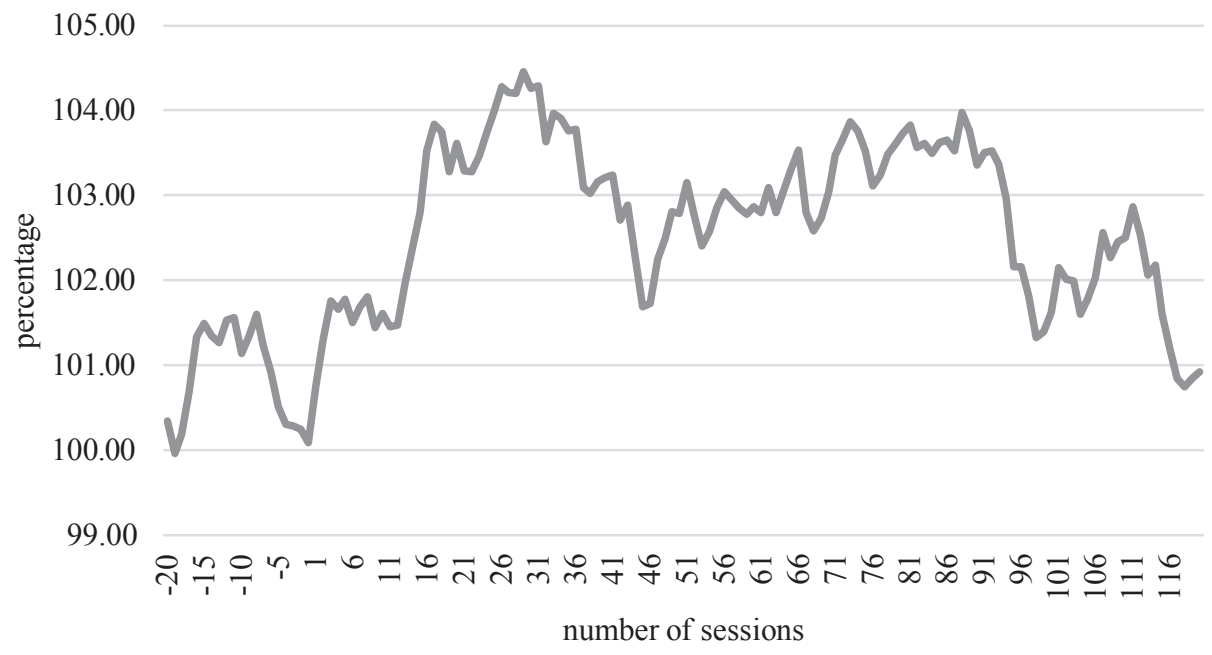

Fig. 3. The value of the portfolio increase above the sWIG80 index

Source: own study.

(sWIG80). In turn, no statistically significant changes in the researched group's observations were observed in the entire research period. It turned out that during the designated 7 months, they rose just 0.93 percent more than the sWIG80 index.

\section{Conclusion}

The research shows that there is a statistically weak relationship between company rates and the moment when they change the place of quotation debuting in the new stock exchange index. It turns out that a month before the change in the stock index, the shares of these companies slightly increase while creating a moderate upward trend. The average growth of these companies during the 20 sessions before entering the new stock market index was 0.52 percentage points higher than the benchmark (WIG20, mWIG40, sWIG80). Where does this relationship come from? This is probably related to the discounting of the future. This regularity is well described in the stock market maxim "Buy rumours, sell facts" that the stock market is discounting the future.

Not much can be concluded after the results of the research for the first month of listing of companies after their debut in the new stock exchange index. The analysis shows that the quotations of these companies behave in a comparable way as the benchmark (WIG20, mWIG40, sWIG80). The calculations showed that the prices of these companies marginally decreased by 0.12 percent more than the benchmark. 
Table 1. Increase in company quotes above the stock index one month before and one month after entering the new index

\begin{tabular}{|l|c|c|}
\hline Stock index & $\begin{array}{c}\text { The increase in the listings } \\
\text { of companies above the stock market } \\
\text { index one month before entering } \\
\text { the new index (in percentage points) }\end{array}$ & $\begin{array}{c}\text { Increase in company quotes above } \\
\text { the stock index a month after entering } \\
\text { the new index (in percentage points) }\end{array}$ \\
\hline WIG20 & +2.63 & -3.23 \\
\hline mWIG40 & -1.16 & -0.66 \\
\hline sWIG80 & +0.09 & +3.52 \\
\hline Average & +0.52 & -0.12 \\
\hline
\end{tabular}

Source: own study.

More interesting conclusions come from research for the longer time horizon. It turns out that in the first six months after the debut in the new stock exchange index, the quotes of these companies behave better than the benchmark. The analysis showed that during this time, company rates are up 0.97 percent more than a benchmark.

Table 2. Increase in company quotes above the stock market index six months after entering the new index and throughout the research period (seven months)

\begin{tabular}{|l|c|c|}
\hline \multicolumn{1}{|c|}{ Stock index } & $\begin{array}{c}\text { The increase in the listings } \\
\text { of companies above the stock market } \\
\text { index six months after entering the } \\
\text { new index (in percentage points) }\end{array}$ & $\begin{array}{c}\text { The increase in the listings } \\
\text { of companies above the stock } \\
\text { exchange index throughout the } \\
\text { research period (seven months) } \\
\text { (in percentage points) }\end{array}$ \\
\hline WIG20 & -1.90 & +0.67 \\
\hline mWIG40 & +3.99 & +2.79 \\
\hline sWIG80 & +0.83 & +0.93 \\
\hline Average & +0.97 & +1.46 \\
\hline
\end{tabular}

Source: own study.

A more positive relationship occurs for the whole researched period, from which it results that the quotations of these companies increased by 1.46 percentage points more than the benchmark. This is a statistically significant relationship which has a positive effect on the portfolio of companies debuting in the new stock exchange index.

This is particularly noticeable in the segment of small and medium companies, and probably linked with that is the stronger efficiency of information, which is characteristic for the segment of medium and small companies. Therefore, the largest increase in the price of companies above the benchmark occurs in the group of companies debuting successively in the mWIG40 index, sWIG80 and finally the WIG20. Market research shows that small companies are the most 
sensitive to market messages and thus more efficiently evaluate the current market situation. In addition, it is worth noting that these companies are not the underlying instrument for futures contracts, thanks to which these companies are not the subject of interest on the stock exchange speculators. As a result, it seems that they value market communications better.

The research on the impact of the change in the stock index on share prices should be continued in the future in order to verify the results of the research achieved in this work. This should be extended with a detailed analysis of the liquidity and volatility of share quotations in order to estimate extraordinary changes in the trading volume and risk level occurring before and after the change in the stock index. It is likely that the researched group may grow significantly in the forthcoming years.

\section{Bibliography}

Baker H.K., Edelman R.B., 1992, AMEX-to-NYSE transfers, market microstructure and shareholder wealth, Financial Management, vol. 21(4), pp. 60-72.

Bennett P., Wei L., 2006, Market structure, fragmentation and market quality, Journal of Financial Markets, vol. 9, pp. 49-78.

Bessembinder H., 1999, Trade execution costs on NASDAQ and the NYSE: a post-reform comparison, Journal of Financial and Quantitative Analysis, vol. 34(3), pp. 387-407.

Fama E.F., Fisher L., Jensen M.C., Roll R., 1969, The adjustment of stock prices to new information, International Review no 10, pp. 1-21.

Grammatikos T., Papaioannou G. (1986), Market reaction to NYSE listings: Tests of the marketability gains hypothesis, "Journal of Financial Research", vol. 9(3), pp. 215-228.

Jenkinson T., Ramadorai T., 2012, Does One Size Fit All? The Consequences of Switching Markets with Different Regulatory Standards, AFA 2008 New Orleans Meetings Paper European Corporate Governance Institute - Finance Working Paper No. 212/2008, version 2012.

Kadlec G.B., McConnell J.J., 1994, The effect of market segmentation and illiquidity on asset prices: Evidence from exchange listings, Journal of Finance, vol. 49(2), pp. 611-636.

McConnell J.J., Sanger G.C., 1984, A trading strategy for new listings on the NYSE, Financial Analysts Journal, vol. 40(1), pp. 34-38.

Merton R.C., 1987, Presidential address: a simple model of capital market equilibrium with incomplete information, Journal of Finance, vol. 42, pp. 483-510.

Pankaj K.J., Jang-Chul K., 2006, Investor recognition, liquidity, and exchange listings in the reformed markets, Financial Management, Summer, pp. 21-42.

Sapp T.R., Yan X., 2003, The NASDAQ-AMEX Merger, NASDAQ Reforms, and the Liquidity of Small Firms, Journal of Financial Research, vol. 26, pp. 225-242.

Załącznik do Uchwały nr 832/2016 Zarządu Giełdy Papierów Wartościowych w Warszawie S.A. z dnia 11 sierpnia 2016 r., s. 1-13.

[www 1] Giełda Papierów Wartościowych w Warszawie, Komunikaty indeksowe, https:/www.gpw.pl/ komunikaty_indeksowe (dostęp: 20.12.2016). 


\section{WPLYW ZMIANY INDEKSU GIELDOWEGO NA CENE AKCJI POLSKICH SPÓŁEK GIEŁDOWYCH}

Streszczenie: Celem artykułu jest analiza zmiany notowań polskich spółek giełdowych, które zmieniają indeks giełdowy w ramach okresowej zmiany składu indeksu giełdowego WIG20, mWIG40 oraz sWIG80. Metodyka badawcza wykorzystuje nadwyżkowe stopy zwrotu (Abnormal Return, AR) na podstawie dziennych logarytmicznych stóp zwrotu polskich spółek giełdowych oraz dziennych logarytmicznych stóp zwrotu indeksów giełdowych (WIG20, mWIG40, sWIG80). W ten sposób określono siłę relatywną notowanych akcji w stosunku do indeksów giełdowych miesiąc przed rewizją składu indeksu giełdowego, kiedy sporządzana jest lista spółek zmieniających skład indeksów. Poza tym zbadano siłę relatywną notowanych akcji w stosunku do indeksów giełdowych po rewizji składu indeksu giełdowego w perspektywie krótkoterminowej (1 miesiąc) oraz perspektywie średnioterminowej (6 miesięcy). Badania przeprowadzono na podstawie kwartalnych zmian składu indeksów giełdowych w latach 2010-2015. Analizy wskazują na występowanie dodatnich nadwyżkowych stóp zwrotu z akcji miesiąc przed zmianą indeksu giełdowego. Średni przyrost notowań tych spółek ponad indeks giełdowy w tym czasie wyniósł $+0,52$ pkt proc. Z kolei średni przyrost notowań debiutujących spółek w nowym indeksie giełdowym w perspektywie 6 miesięcy po debiucie wyniósł $+0,97$ pkt proc. ponad benchmark (WIG20, mWIG40, sWIG80).

Słowa kluczowe: indeks giełdowy, Giełda Papierów Wartościowych w Warszawie, rynek kapitałowy, strategia inwestycyjna. 